\title{
Equality and gender amongst young Basque People: A crossroads OF CONTINUITIES, CONFLICTS AND RUPTURES ${ }^{1}$
}

IGUALDAD Y GÉNERO ENTRE LA JUVENTUD VASCA: CONFLUENCIA DE CONTINUIDADES, CONFLICTOS Y RUPTURAS

\section{Mari Luz Esteban Galarza; Jone Miren Hernández García; Elixabete Imaz Martínez}

\author{
Universidad del País Vasco (UPV/EHU); ml.esteban@ehu.eus
}

\begin{tabular}{ll} 
Historia editorial & Abstract \\
\cline { 2 - 2 } $\begin{array}{l}\text { Recibido: 06-07-2015 } \\
\text { Primera revisión: 10-09-2016 }\end{array}$ & $\begin{array}{l}\text { The aim of the research we present in this article is to offer a general overview of } \\
\text { the situation in the Basque Country concerning gender equality/inequality among } \\
\text { Aceptado: 09-04-2017 }\end{array}$ \\
$\begin{array}{l}\text { young people. This paper is based on qualitative research conducted with young } \\
\text { Basque people (15-30 years old). In the first part, a portrait of the young Basque } \\
\text { population is presented with regard to formal equality and changes occurring in }\end{array}$ \\
$\begin{array}{l}\text { Spanish and Basque society over the last three decades, as well as a brief review of } \\
\text { Gender }\end{array}$ & $\begin{array}{l}\text { youth studies focusing on gender analysis. In the second part, the main results of } \\
\text { this research are outlined, following three main lines of enquiry in relation to the } \\
\text { Inequality }\end{array}$ \\
Conflicts & $\begin{array}{l}\text { maintenance or transformation of asymmetrical gender models: continuities, con- } \\
\text { flicts and ruptures. }\end{array}$
\end{tabular}

\section{Resumen}

Palabras clave

Género

País Vasco

Desigualdad

Conflictos

En este artículo ofrecemos un diagnóstico general sobre la situación de igualdad/desigualdad de género entre la juventud vasca. El artículo está basado en una investigación cualitativa llevada a cabo con jóvenes vascas/os de entre 15 y 30 años. En la primera parte se abordan dos aspectos. Inicialmente, se hace un retrato de la población vasca joven en relación a la igualdad formal y a los cambios ocurridos tanto en la sociedad española como en la vasca en las tres últimas décadas. A continuación, se realiza una breve revisión de los estudios sobre juventud focalizando en el análisis de las relaciones de género. En la segunda parte del texto, se comentarán los principales resultados obtenidos en el estudio, ordenados de acuerdo a tres grandes apartados relacionados con el mantenimiento o transformación de modelos desiguales de género; esto es, incidiendo en las continuidades, los conflictos y las rupturas.

Esteban Galarza, Mari Luz; Hernández García, Jone Miren \& Imaz Martínez, Elixabete (2017). Equality and gender amongst young Basque people: A crossroads of continuities, conflicts and ruptures. Athenea Digital, 17(2), 31-55. http://dx.doi.org/10.5565/rev/athenea. 1675

\section{Introduction}

The objective of the research we present in this article is to identify and analyse continuities, conflicts and ruptures regarding gender among Basque youth, ${ }^{2}$ continuities, conflicts and ruptures that, in our view, are directly related to legislative, institutional,

\footnotetext{
1 This article has been translated by Beatriz Moral and Cameron Watson and corrected by Margaret Bullen. We would like to thank them for translating and revising this text.

2 The research project "Continuities, conflicts and ruptures concerning inequality: gender relations and body and emotional practices among Basque youth", was funded by the Spanish Ministry of Science and Innovation (MICINN) (FEM2009-07679, FEME) and the University of the Basque Country (UPV/EHU) (EHU09/32) during the period 2010-2012. Mari Luz Esteban Galarza was the principle investigator of the project in which Jone $M$. Hernández García and Elixabete Imaz Martínez took part.
} 
social and cultural changes of the last thirty years in Spain in general and in the Basque Country in particular.

In the Basque context, youth has been an area of interest for feminist and gender studies. Yet most research has been partial (see, for example, Estébanez \& Vazquez, 2013), applied ${ }^{3}$ (e.g. Argoitia, 2011) and quantitative (e.g. Masa, 2009). For that reason, in setting out our research we opt for an outline which seeks to complement and expand on the work undertaken to date. We thus think it interesting to undertake a study that sketches out - in general terms - the situation regarding young Basque people when it comes to gender equality, a comprehensive (as regards the age span concerned - young people between 15 and 30 years of age) and diverse (as regards thematic object of analysis) study which will allow us to capture a snapshot of the moment and raise questions of interest for future research.

The current paper attempts to set out some of the main ideas and conclusions drawn from the final report, in the form of a general overview which offers certain elements for consideration and raises questions which can be added to the debates currently taking place surrounding gender and youth in other ethnographic contexts in Europe and, in general, the West.

The methodology developed in the study combines a traditional qualitative approach, based on interviews and discussion groups, and the ethnographic focus characteristic of social anthropology. As such, we have interviewed 60 girls and 42 boys resident in the Basque Autonomous Community ${ }^{4}$, and conducted participant observation in different events in which young people take part, such as sports activities, festivals, cultural exhibitions, feminist workshops and concerts. Given that this is qualitative research, we have focused our attention on a middle and lower-middle class population in order to avoid excessive heterogeneity and complexity in the sample. When it came to choosing the participants in the study, sexual orientation was not a variable taken into consideration, although in some interviews participants did identify themselves as homosexual. This in itself, however, does not allow us to draw any conclusions regarding the LGTB youth group.

The fieldwork was carried out mostly during 2011 and 2012. Members of the research group were personally responsible for looking for and contacting people to in-

\footnotetext{
3 When we say applied research, we are referring to work sponsored by bodies or entities responsible for developing equality policies, which usually promote research that might serve as the basis for public authority programmes or activities.

4 The Basque Autonomous Community (comprising the provinces of Araba, Bizkaia and Gipuzkoa), together with the Autonomous Community of Navarra, constitutes the area of the Basque Country located within Spanish borders. For a general overview of feminist studies carried out in the Basque Country in the field of social sciences, see: Jone M. Hernández and Elixabete Imaz (2010).
} 
terview. The meetings were held in different parts of the Basque Country, mainly in the towns where those interviewed lived. Each interview took place in one single session and was led by a person on the research team in charge of posing a set of previously drawn-up questions. The different interviews were carried out on the basis of common guidelines for the whole research group. In these guidelines, there were different sections or areas of study in which an attempt was made to ascertain information through a variety of questions or specific queries. The sections around which the guidelines were drawn up served as an outline for the final report, the results of the research. These sections are the following: perceptions of feminism and equality, leisure time, friendship, group of friends, places where young people hang out, education, love and sexual relationships, the body, family, fatherhood and motherhood, work and the world of work.

Individual interviews lasted approximately 90 minutes; 120 minutes in the case of group interviews. They were all recorded in audio format and later transcribed in detail in order to analyse them. The material resulting from this process then formed an object of debate and reflection in different working sessions in which all the members of the research team took part. In those sessions, the material collected was analysed and organised around different units of analysis which, in practice, shaped the outline for elaborating the final document. Making full use of the information gathered centred on analysing the discourse and studying the practices of the young people who were the object of the research.

The theoretical frame for this research is the feminist analysis of gender relations, particularly of the kind currently being conducted in social anthropology. Within this frame, societies are understood to be formed by gender systems where inequalities in the distribution of power and prestige, division of labour, and sexual, corporal and emotional socializations and configurations are reproduced and/or transformed among individuals socially defined as women and men. These inequalities are not always reproduced in the same way in every society or sector (Connell, 1987; del Valle, 2002; Saltzman, 1991). We understand that gender is a relational concept, referring to the way in which social practice is organized (Connell, 1987) and is always related to other variables such as social class, age, ethnicity or sexual orientation. We have complemented this perspective with Judith Butler's performative theory of gender (Butler, 1993, 1997) and feminist reviews of Gramscian perspectives on hegemony/subalternity (Juliano, 1992; 1998). In addition we have used feminist approaches to the theory of practice (Esteban, 2004; Ortner, 1984) that build on the work of authors such as Anthony Giddens (1984) or Pierre Bourdieu (1979/1984). One of the fundamental references for our research is youth studies (to which we refer below) but we also draw on 
other areas of enquiry, particularly those located in the Basque context: men and masculinity (Bullen \& Egido, 2003; Díez, 1996); emotions and love (Esteban, 2011; Medina, 2012); family and maternity (Díez, 1999; Imaz, 2010); gender relations and sports (Díez, 1996, 2003; Díez \& Hernández, 2008); and gender and ritual (Bullen \& Díez, 2002; Bullen \& Egido, 2003).

In the first part of the article, we sketch a portrait of the young population of the Basque Autonomous Community with regard to formal equality and changes taking place over the last few decades. Then we review youth studies, especially those focusing on gender relations. In the second part, the main results of this research are outlined, following the three main lines of enquiry in relation to the maintenance or transformation of asymmetrical gender models: continuities, conflicts and ruptures. These three concepts make up the main bases around which the analysis of the data collected in the research was organized and, in our opinion, sum up perfectly the logics which today underlie the experiences of young Basques in relation to gender equality.

\section{Young people in the contemporary Basque Country: some data on the achievements and limits of equality}

We can picture contemporary Basque society as formally egalitarian as far as gender relations are concerned not only at a legal level but also in political, institutional, educational and employment matters. This society is open to change and favours, for example, institutional implication in the achievement of equality between women and men, different kind of families or freedom of sexual choice, thereby situating itself at the forefront of European public policy on the subject of gender equality (Bustelo \& Lombardo, 2007).

This is also reflected in the opinions which the young people reveal regarding questions such as the outright rejection of gender violence, the wide-ranging tolerance towards the diversity of sexual orientation or a perception of the family as a space in which one must give precedence to equality amongst its members (Fernández-Llebrez González \& Camas García, 2010).

Today's society comprises several generations who were born and raised in the post-dictatorial period and have been socialized in the theoretical acknowledgement of the right to equality. This right is not only accepted by the vast majority of the population but also assumed by institutions as being their responsibility to promote. 
This situation stands in contrast to the not so distant past of a State in which Francoism (1939-1975) reduced women to the role of mothers and housewives, subordinated to their husbands and to the principles of national Catholicism (Roca i Girona, 1996). Later, the generation of mothers of today's youth, born in the 1950's and early 1960 's, led to the collapse of the hegemonic model of femininity: they joined the labour market in mass, prioritized education as a means to emancipation, participated in social and feminist movements, developed lifestyles foreign to normative femininity and promoted an egalitarian, not complementary, model of the couple (Garrido, 1992; Miranda, 1987; Tobio, 2006).

Let us now see some data relating to young people in the Basque Country, which will allow us to get a snapshot of the current Basque context, in relation to that of Spain and Europe.

First, one should point out that the number of young people in the Basque Autonomous Community is in decline. According to the Basque public broadcast service (2016), in the period between 2011 and 2014 the number of young people fell by half (from 448,000 to 290,000). Moreover, if we compare the ratio of young people in the Basque Country to that of the State as a whole, we see that the Basque Autonomous Community has the second lowest level, a tendency towards decline which began in $2000(22.2 \%)$ and became even more pronounced until dropping to $13.2 \%$ in 2015 . As the Basque Youth Observatory (2016) points out, this level is also below that of the European average (17.5\%).

Likewise, the data relating to the work situation demonstrate notable differences with those of neighbouring societies. Whilst the youth unemployment rate in the State as a whole was 49.6\% - one of the highest in Europe - in 2015 (García Campos, 2015). In the fourth quarter that same year -and as the Basque Government (2016) said-, the unemployment level amongst the population in the Basque Autonomous Community aged 16 to 29 was $25.6 \%$ (28.5\% amongst men and $22.5 \%$ amongst women, respectively).

Turning to the parameters surrounding the entry into adult life, one might say that, in general terms, in the Basque Country young people - defined as that stretch of time between childhood and adulthood - are defined as such during a much longer period than in previous generations. The data describe a profile of young people leaving the family home late and an emancipation of this type similar to or even later than the State, where, according Eurostat data, the average leaving home age in the case of young women is 27.9 whereas in the case of young men it is 29.8 (Eurostat, 2015, p. 46). As regards the residence emancipation rate amongst young people between 25 and 29 in the Basque Autonomous Community, it is calculated at 46\% (López Oller, 
2014 , p. 50). The high youth unemployment rate explains to some extent the fact that young people stay with their family of origin, but beyond these economic difficulties, other sociocultural factors should be taken into account (Moreno, 2012). For instance, in Spain as a whole, emancipation from the parental home is found to have more to do with the intention of starting a family than with personal maturity (Gaviria, 2005).

In any event, the prolonged residency of young Basques in the original family home has repercussions in the fact that family formation is generally late. Thus, according to the latest Eustat data in 2014, the average marriage age for men who marry for the first time was 35.7, whilst in the case of women this same average was $33.6^{5}$. As regards maternity, the average age of women who gave birth in 2013 was 32.7 and only $18.8 \%$ of births in 2013 were by women under 30 years of age, which suggests that Basque women continue to put off maternity until increasingly older ages (Emakunde, 2015, p. 28). Without - regrettably - having any data regarding the young men in this same situation, one can only suppose that we would come across a similar delay in the case of paternity.

With regard to education, there has been a substantial transformation in the Basque Autonomous Community over the last three decades, manifest in the creation of a state university and with it an increase in the access of the lower to middle classes to university education. In addition, knowledge and university education have been increasingly valued in the last few decades and this too has been highly significant for women. The data confirms this change. In 1981, only $10 \%$ of Basque women aged between 25 and 29 had a university degree (Arregui, 1987), while in 2010 it was $31.7 \%$ (against $20.7 \%$ of men). Moreover, - as the University of the Basque Country (UPV/EHU) (2011) said - in 2011, 55\% of the students registered at the public University ${ }^{6}$ were women.

However, as in other European countries (Iannelli \& Smyth, 2008), a clear distinction persists when it comes to choosing a career, a factor which accounts for the fact that some professional fields are still "out of bounds" for women. According to UPV/EHU data for the 2010/11 academic year, 48.3\% of young men chose technical courses, compared to only $17.4 \%$ of young women who preferred fields related to education and health. Gender bias is clear not only in the choice of higher education, but also in young men's preference for vocational training as electricians or metal workers, for example.

\footnotetext{
It is worth highlighting that, in $49 \%$ of cases, the couple already lived together prior to marriage, although unfor tunately there are still very few data on the extent and features of this kind of cohabitation and family formation.

6 The only public university in the Basque Autonomous Community and the one that has by far the greatest number of students.
} 
Whatever the case, in order to analyse the continuation or not of social inequalities between young women and young men (the goal of this study) it is necessary to look at other fields which are difficult to quantify. As we will see now, when referring to European societies as a whole, the situation in these fields demonstrates that gender inequality not only continues, but is reproduced and even intensified, or redefined amongst the younger generations, as Ana de Miguel signals referring to Spain (2008).

This inequality is obvious in certain phenomena such as the sexualization of young women's and teenagers' bodies, an issue already addressed in diverse European studies (Griffin, Szmigin, Bengry-Howell, Hackley, \& Mistral, 2013; Liotard \& JamainSamson, 2011; Walter, 2012), and the severe constraints imposed by models of the body as new forms of discipline and control of women (Liimakka, 2008); the prominent place of sport - a field where hegemonic masculinity is clearly exalted - in the use of leisure time and in the construction of most young men and women's subjectivity (Díez, 2003); peer group socialization and consumption as arenas for the reinforcement of gender stereotypes (de Miguel, 2008); the persistence of unequal relationship arrangements in couples (Esteban \& Távora, 2008); or the assumptions that violence and possessive feelings are natural ingredients of love relationships (de Miguel, 2008). Focusing on the Basque context, we would underscore the growing interest in youth studies which, moreover, are progressively incorporating the gender perspective in their analyses of different realities which affect young Basques. Taking into account the subject matter of our research, we would highlight studies aimed at analysing practices linked to leisure (Alvarez Molés, 2012) and festive rituals ${ }^{7}$, both spheres which play a big role in the routines of young people and Basque society as a whole.

In reference to young men, there is an apparent contradiction in that whilst they give lip service to equality, in practice they show resistance to change, a fact which some of them are ready to admit and many women confirm (Fernández-Llebrez González \& Camas García, 2010). This contradiction may be related to the perception of "power as limited good" that makes achievements in equality appear to be a reduction in men's power (Del Valle, 2002, p. 43) together with a logic that requires the exaltation and the permanent exhibition of masculinity (García García, 2010).

\footnotetext{
The festive space has come to be one of the areas of most interest for analysing gender in Basque society. To the "classic" studies addressing the festive ritual of the Alardes in Irun and Hondarribia (Bullen \& Egido, 2003) one should add a book by anthropologist Miren Guillo (2016) in which studies are presented that imply a critical revision of the fiesta model characteristic of the Basque context, from the perspective of gender. This approach to conceiving fiestas from an academic viewpoint coincides with a growing social conscience about the need to rethink fiestas from the perspective of gender, as demonstrated by the significant social mobilizations which took place during the summer of 2016 in numerous Basque towns and in which there was mass protest against different sexual assaults that had taken place in the festive context. This climate of protest and the different initiatives resulting thereof constitute new practices about which further research is necessary.
} 


\section{The place of gender inequality in youth studies}

The concept of youth as an analytical category became relevant in the first decades of the twentieth century when there was a concern for the generation gap and emergent subcultures, conceived as a problem (Bantigny \& Jablonka, 2009; Feixa, 1996). A classic definition of youth understands it to be:

The phase of individual life between physiological puberty (a "natural" condition) and the acknowledgment of adult status (a "cultural" condition). Youth has been seen as a universal condition, a phase of human development to be found in every society and period of history. From this perspective, the need for a period of preparation between children's dependency and full social integration, and the crisis and conflicts of this age group, are determined by the nature of the human species. (Feixa, 1998, p. 16)

Yet as has been argued, both from the perspective of social anthropology and that of youth studies in general, we must specify what are we talking about when we refer to puberty and/or youth and situate these terms firmly in their historical, social and cultural context.

The research on youth conducted in anthropology and the social sciences can be divided into three groups. The first has to do with the studies of marginal young people or disadvantaged class groups, generally oriented to the reintegration of young people at risk of social exclusion. In this research, youth is considered as a period of risk, but also as the last chance for social reintegration of marginalized groups, characterized by drug consumption, juvenile delinquency, risk factors in consumption habits or young motherhood and fatherhood (Feixa \& Porzio, 2004). The second group comprises the study of youth subcultures, which came to the fore with the analysis of music styles in the 1980s. Here youth was approached as a social problem, underlying which was the fear of social disintegration (Feixa, 2005). The third group is concerned with the transition to adulthood, where youth is understood as a process by which to acquire personal autonomy and economic independence until the person is fully considered an adult. In this case, ethnographies and research try to plot the paths and mark out the milestones of this transition, as well as its social and personal consequences. These might include: access to the labour market, family training and parenthood (Casado, 2006; Imaz, 2010), change of sociability and friendship networks (Bidart \& Pelissier, 2002), or leaving the family home (Gaviria, 2005). In the current study, the literature stemming from each of these lines of enquiry has been consulted and the most appropriate arguments, when it comes to the initial theoretical-methodological approach and the ethnographic context, adopted. 
Despite the existence of an extensive literature on and empirical approaches about young people, the research focused on the continuities and changes in the assimilation of the idea of gender equality among young people is scarce. Young women and men are usually taken as a single category, and no difference is made between men and women's opinions, attitudes and values. In the Spanish academic world the studies of Fernando Fernández-Llebrez González and Francisco Camas García (2010), Javier Elzo (2005), Inés Alberdi, Pilar Escario and Natalia Matas (2000) and Roger Martínez (2002), which specifically address gender inequality among young people, represent an exception. It is true that in some cases, gender has a particular centrality, as in the following pieces of research: the consumption of synthetic drugs among women (Romo, 2001), homophobia among teenagers (Pichardo, 2009) or military service as a masculine rite of passage (Zulaika, 1989). However, we must reiterate that youth studies, which so often insist on educational level or social class, tend to ignore gender differences and do not consider gender to be a significant variable. Moreover, research on gender and youth is usually conducted by professionals specialised in gender and not in youth (Alberdi et al., 2000). Outside Spain, too, there are a lower number of works published in specialized journals which refer to gender relations among young people in comparison to other youth analyses. Although in recent years there have been exceptions which make up an interesting contribution to our work, as one can note throughout the text.

It is interesting to note that several Spanish authors agree that youth is the period of life where inequalities between sexes are less obvious. Amparo Lasén (1999) talks about a "temporary generational model" where these differences are absent and where masculine and feminine trajectories go practically hand in hand; young women and men seem to follow the same pattern of time use, they have the same interests and they do the same kind of activities. Ramón Ramos (1990) points out that differences in time use to women's disadvantage do not tend to show until they reach their thirties, yet higher levels of education and singleness would contribute to greater equality in this respect, not only in the use of time in educational and professional spheres, but also in leisure.

According to these authors, there is a biographical period of relative equality concerning similar time use that Ramos has referred to as "juvenile academic democracy", a transient state that comes to an end with integration into the workforce, but particularly with cohabitation. At this point, the institutions (work, family) that traditionally reproduce discrimination against women re-emerge clearly. They assert then that during youth, inequalities are temporarily suspended or interrupted. However, as we will show in the subsequent sections of this paper, the results of our research challenge 
this idea of youth as a period where inequalities between young women and men are suspended.

Firstly, the testimonies of our interviewees make it clear that there is a gap between social discourse and their own experience concerning education or employment, for instance. Secondly, despite the diversity of situations, experiences and practices associated with "being young" and the fact that economic autonomy or leaving the parental home (whether or not to live with someone else) can bring about changes in the perception and experience of gender relations, there is a general consensus among the young people interviewed that equality has not been yet achieved, at least not in all spheres of life. Paradoxically, this consensus coexists with the idea that feminism is something anachronistic, something that has to do with their mothers but not with them, a process of disaffection regarding the feminism which we will address later. Finally, we have found both latent and overt conflicts over inequalities between women and men not only in the areas of employment and education but also in leisure, sexual and emotional experience, body image or maternity.

Our question is then: what makes young people more aware or more critical of inequality and its causes? In our view, there are two key aspects that foster a critical attitude which challenges hegemonic gender ideals or values (which we will come back to in the final section). First and foremost is the degree of influence of feminist ideology in the areas in which young people move. In second place, is the contribution of anything that leads to the approval and ritualization of the social and collective participation of women (in sports, formal or informal associations, etc.), as well as the normalization of young men's participation in non "masculinizing" spheres or activities, such as dance.

\section{Continuities: differential socialization, stereotypes and dichotomies in gender}

In a social context of change such as that described in previous sections, where progress for women is irrefutable, there are certain spheres where continuities, both at the level of representations and of practices, are more than evident and which coexist in a paradoxical way with the social transformations that have taken place. In this section we focus on these continuities, revealing a general overview of them which allows us to identify thereafter where (and why) conflicts and ruptures emerge.

One of the findings of our research is that stereotypes and classical dichotomous gender models are still in place, both at the symbolical and practical level. A differenti- 
ation that tends to be completely naturalized, which is reflected in different aspects of life that we will now discuss.

Young people interviewed recognize a significant diversity of models for women and men in today's Basque society, yet at the same time they maintain a clearly dimorphic and dichotomous approach to physical, character and behavioural aspects. In these dichotomous models, difference is not questioned and it is assumed that girls and boys are diametrically opposed beings. Moreover, the idea prevails that differences will never disappear, no matter how much progress is achieved in equality.

It seems that stereotypes based on attributes and behaviours considered appropriate and advisable for girls and boys have not suffered changes of note. At the same time, an approach that naturalizes life prevails, materialized particularly in the idea that maternity is something fundamental to women's identity, an unavoidable destiny for them.

Furthermore, family is still very important both as an individual source of support and frame of reference, as we have seen previously, but also as a goal to work towards and a model for life. In our interviews, references to ways of life not organized around a classical family model were few and far between ${ }^{8}$.

An influential factor in this hegemonic family scheme is the centrality of the couple in a totally romanticised Western cultural imaginary where, in spite of the diversity of family forms, the nuclear family formed by a heterosexual couple becomes the ideal model when it comes to organising cohabitation (Esteban, 2011). In relation to this, becoming a parent is usually considered the final step on the road to the adult world, once studies are completed, the parental home abandoned, an intimate partner found and one's professional situation stabilized (Imaz, 2010). These stages make up the single script of an imaginary life itinerary, which does not correspond to reality ${ }^{9}$ but has a direct influence on the way life is anticipated.

This process is also related to a totally genderized socialization from an early age. From the age of 3-4, girls and boys perceive themselves as different from each other, and adopt behaviour, clothing styles and ways of playing in keeping with this sexual differentiation. This bipolar image of humans is transmitted to them through diverse

\footnotetext{
${ }_{8}$ Most of the young people interviewed for this research still live with their parents and have no children, including the older ones. Exceptions are university students sharing a flat with other students or friends, some of whom live with their partners. Only 6 out of 25 young people interviewed have children ( 5 women and 1 man), all of them are still babies.

9 As regards the changes which take place in the final decades of the transition between being young and being an adult there is nowadays a consensus in youth studies concerning a greater complexity in this process which would be indicated, among other things, by the fact that the passage from school to employment is neither lineal or predictable; a consensus clarified by authors like Andy Furlong, Fred Cartmel and Andy Biggart (2006).
} 
yet powerful channels: the market (toy and clothing stores), the media, education (where pictures are used at school showing differentiated genitals to enable identification with a male or female sex).

A specific field where sex differences are learnt and naturalized is sport in general and football in particular, constituting a privileged area for promoting heterosexist masculinity (Díez, 1996; Díez \& Hernández, 2008). While interviewees do not perceive girls and boys to be treated differently at school in terms of the transmission of knowledge in the classroom, they do mention a different way of dealing with girls and boys' physical education. In this case, it seems to be taken for granted that girls are not very good at sports.

Another sphere where hegemonic masculinity is reinforced is partying or fiesta. Partying is a time and place devoted to fun and seduction, but also to a kind of male socialization that reinforces what is at times a traditional model of masculinity, where men's social superiority is naturalized. That is why some of the young men allude to leisure projects (dinners, trips...) they carry out with their girlfriends (when they have one), but stress that they would never party with them. Girls, of course, say that they party too, but when boys go out with their friends it seems to be synonymous with going wild, losing control. As we understand it, partying contributes directly to the constitution of a specific gender identity that paradoxically (even for the men) puts on hold their critical attitude towards differences between women and men, and allows a more "traditional" masculinity, bordering on sexist, to emerge (Esteban, 2011) ${ }^{10}$.

Focusing on women's socialization, fear emerges as a key element that restricts their management of time and space, as well as feeding into the rhetoric of controlling women's lives. Despite the violence between young men, as we can see in games and demonstration of virility or when it comes to punishing a man who is considered "not man enough", fear is not associated with being a man, but rather with being a woman. Moreover, women tend to exclude men from the fear they share: they are not women, so they cannot understand women's fear of sexual aggression. Men are more afraid of being assaulted (more than one of the young men interviewed reported having been attacked), but they recognize it is not the same as suffering a sexual assault ${ }^{11}$. Follow-

\footnotetext{
${ }^{10}$ Christine Griffin et al. (2013), in their analysis of the changes which have taken place in the United Kingdom in shaping the femininity of young girls, call attention to the consequences they confront when faced with the obligation of being sexy, independent but not feminists, in the context of a culture of leisure where they must drink but never as much as the boys.

${ }^{11}$ Whilst it is a relevant topic and one about which there is growing awareness, in this study we have not addressed the fear of assault from the specific perspective of young LGTB people. There are recent, although limited, studies on this question in the Basque Country such as, for example, that of Gehitu and Guztiok Elkartea (2014), which includes data relating to homophobic assaults witness and/or experienced by schoolchildren and attitudes towards such assaults. Another interesting addition is a publication by the Basque public advocate, the
} 
ing this line of thought, being a woman somehow means sharing the fear of being physically and sexually abused, experiencing that fear, embracing it and socializing $\mathrm{it}^{12}$.

Another area of life where we can find clear continuities is body image. Although ideals of perfection and beauty affect both women and men, girls are more easily objectified than boys and, in short, more vulnerable to criticism. All our informers (particularly women) are perfectly aware of the cult of body image, and the majority of them are also aware of its risks and critical of the pressure girls have to bear. This pressure does not affect men in the same way, despite some isolated cases of boys worrying about their looks and feeling self-conscious because they compare their image with pictures in magazines.

When it comes to sexuality, even though young women today enjoy more freedom, some attitudes are still dominated by hegemonic values which exalt virility and male sexuality to the detriment of women (who still have to endure criticism for flirting or for being "too" sexually active) and non-heterosexual people. A bittersweet conclusion is that, although girls today seem to be more active when it comes to going out, flirting and picking up boys, and no longer need the boy to take the initiative, a girl who flirts too much or picks up too many boys is penalized by society.

Homosexuality is also a node of inequality and, ultimately, a mirror of how heteronormativity is one of the main pillars of gender inequalities. Of our interviewees who engage in heterosexual practices, only a few have spontaneously mentioned homosexual relationships. It is taken for granted that "normal" is the relationship between a woman and a man. Only when directly questioned do they express their opinion about other kinds of relations. It is evident from our interviews that there is a certain cultural normalization of homosexuality probably related to changes in legal matters occurring in Spain over the last decades (gay marriage, gay parent adoption) and in mass media images. This acceptance, however, is more theoretical than practical (Pichardo, 2009).

Ararteko (2009), which includes diverse contributions regarding attitudes towards sexual diversity ion the part of young people.

${ }^{12}$ In the Basque context, Teresa del Valle, in her book Andamios para una nueva ciudad (1997), uses the metaphor of the forbidden city and the places we forbid ourselves, to show that there are many places which are dangerous for women, making them vulnerable and restricting their freedom. 


\section{Conflicts and contradictions: feminism, gender violence, maternity and leisure}

While it is clear that stereotypes, values and roles that favour inequalities between women and men persist, we also have evidence that this gender model has started to crack and contradictions between young people's discourses and practices begin to show.

On the one hand, the idea that sexual discrimination is a thing of the past and that feminism is outdated and irrelevant for today's society is fairly generalized. With the exception of some spheres, many young people see feminism in an extremely negative light, as something related to hatred of men and to women's desire to be superior.

This rejection of feminism among young women, studied in depth by authors like Angela McRobbie (2009), has been well documented in different European countries (Scharff , 2012), highlighting the association that is typically established between feminism, lesbianism, non-femininity and hatred of men, in a society characterized by neoliberalism and individualism, where young women interpret any collective proposal to be detrimental to their own independence (Scharff, 2012). This context of progress in legal equality, on the one hand, and a rejection of feminism, on the other, is being catalogued in the European literature as postfeminism, a term which is at the same time contested (see Scharff, 2012) and which is not being used in either Basque or Spanish society (see Martínez, 2007).

On the other hand, one notes, especially on the part of young girls, a certain capacity to identify some of the black spots darkening the skyline of freedom, self-reliance, independence and interdependence needed to build an egalitarian society. These black spots include control within partner relationships; the emphasis on body image and care; girls' hypersexualization; the exaltation of maternity; and the multiple types of violence against women.

Social problems such as violence against women make young people realize that equality has not been achieved. Violence against women has been an ever-present topic in the interviews undertaken: both girls and boys refer to it without being asked and they consider it one of the main social problems. In our context we have seen that great steps have been taken in order to eradicate it, and we can say that public opinion today rejects violence against women, at least in its most explicit form. Dolors Comas d'Argemir (2011) points out that this very high level of awareness observed in Spanish society has to do with feminist activism and political responses, but above all with the active role played by the media. Such open rejection, hitherto unknown, could be un- 
derstood as an alteration of traditional reference frames in favour of others stemming from the hard fought battles of the feminist movement (Bullen \& FARAPI, 2011).

Research on violence in young couples aged between 18 and 20 in the city of Bilbao (Amurrio, 2008) has demonstrated that the rate of young women reporting abuse is on the increase. Some of the conclusions of this research are in accordance with ours. For instance, the fact that alongside the new egalitarian frames of reference there coexist other social, ideological and symbolic practices. Here, unequal relationship patterns are strengthened thanks to deeply rooted sexist stereotypes which reproduce masculine dominance in some of the most fundamental institutions, such as family and school (Amurrio, 2008, p. 5). This coexistence of old and new models results in young people putting up with situations of psychological violence that could be the threshold of physical and sexual violence. Moreover, this risk, together with bad experiences in young people's love relationships, are a consequence of the still hegemonic ideologies of love and of what it means to be a man or to be a good girl (Amurrio, 2008, p. 6).

Our interviewees explained men's violence against women in different but classical ways: the influence of genes, men's superior strength, the aggressors' childhood traumas or personal problems, socialization and education. Gradually, violence is coming to be perceived as something that is embedded in social and gender systems, associated with changes in gender models: women are not willing to be subject to men anymore and this is what generates the conflict. At the same time, this violence is considered to be an issue of education and socialization. Nevertheless, young people find it hard to imagine that violence can happen in romantic relationships, that a relation which began in love could end in murder. It seems unreal to them that love is constructed as something which drives people to fight, to beat, to kill; they do not usually associate romantic relationships with control and power relations. And we find this worrying, because it prevents the identification of aggressive attitudes and the search for solutions ${ }^{13}$.

With regard to sexuality, there have been certain changes such as the onset of sexual activity at an earlier age than before and the narrowing of the gap between girls and boys with regard to the age of sexual initiation ${ }^{14}$. This is interpreted by some

\footnotetext{
${ }^{13}$ Even so, one should highlight the commitment of a significant number of young Basque people against violence directed towards women. To mention one example, several hundred young people aged between 12 and 26 years of age participate annually in the Beldur Barik (Without Fear) programme, a competition comprised of very distinct activities promoted by Emakunde-The Basque Women's Institute and aided by the main institutions in the Basque Autonomous Community, around 25 November-the International Day for the Elimination of Violence against Women.

${ }^{14}$ The increasingly earlier age at which sexual relations begin, as well as similarity of experience for both girls and boys, is a fact corroborated by every agency and survey (amongst which we would highlight those undertaken
} 
interviewees as increasing the chances of women's vulnerability insofar as the dominant models of sexual practice and pleasure remain the same. Nevertheless, almost all the interviewees coincide in underlining the negative sanctions for girls who are very active sexually.

However, it is during life transitions that conflicts related to inequalities surface: moving in with the love partner and dealing with the housework, or deciding to have a baby and becoming a mother or father. These times of transition are, in practice, crucial and decisive for they mark young people's return and reintegration in the major structures of family and employment, structures which we know to play a fundamental role in the production and reproduction of an unequal gender system.

In all certainty, in our opinion, maternity is one of the spheres where women are at their most vulnerable. Women's autonomy is emphasized when it comes to deciding whether to become a mother or whether to reconcile motherhood with a job, and it is assumed that men will necessarily participate in child care. However, an overwhelming consensus on the idea that the most suitable person to nurture children is a woman, totally restricts co-responsibility and, in short, her theoretical decision-making potential. Therefore, maternity is still reproduced as one of the main locus for conflict and inequality, particularly concerning employment (Imaz, 2016). We should say that none of the interviewed women considered resigning from their jobs, regardless of how hard it is to make work compatible with maternity.

While there is emphasis on the autonomy of women to decide whether to keep or quit a job in order to devote themselves to an infant, it is still considered that having one person devoted to the child during the first years of life is the best option, and it is widely agreed that the mother is the person best suited to this task. Nevertheless, we should point out that the assumption that the mother should have a major role in raising a child, does not imply, discursively at least, returning to the model of the complementary couple where the woman plays the role of housewife. Staying at home to take care of the child is understood as a temporary decision, a decision taken in agreement and in respect of women's autonomy.

We conclude that the continuity in the younger generations of the idea of the mother as irreplaceable, typical of what Sharon Hays (1998) defines as an intensive maternity model, undermines the attainment of the egalitarian couple ideal in real life. This ideal is nonetheless dominant in the discursive field. Closely related to this is the

periodically by the INJUVE-Institute of Young People, in the Spanish State, and the Basque Observatory of Young People. But a problem we have with this information is that it does not specify what the surveys or those sur veyed understand by the "initiation" of relations (whether they are, for example, coital or not); so that nor do we know whether these practices may be changing or even if there may be differences in how girls and boys understand this act. 
issue of the distribution of domestic tasks, where once again, although the idea of equality is clear at the discursive level, in practice these tasks are perceived as a potential arena of conflict.

\section{Ruptures and transgressions that question or reinvent gender identities and practices}

Before addressing the conclusions of the study, we would like to emphasise certain signs of fracture we have noted with regard to traditional socialization, and which allow us to look towards the future with optimism. In spite of resistance to change stemming from the old structures and classical values related to femininities and masculinities, sexuality, romantic love and the exaltation of maternity, we have found new individual attitudes that give (or could give) rise to significant social transformations. We have collected the testimonies of young people in the process of shaping their gender identity and designing life projects outside the established guidelines, refusing the traditional "life path" of getting married and having children, or crossing the dividing lines between women and men, be it in education, sports, culture, labour, leisure, home, demonstrations of love or sexual behaviour.

In the gender identity building process, the elements where social control is stronger are sometimes used as a privileged place for rebellion and resistance, as with experimenting with body image. Some of the women interviewed go beyond a superficial and stereotyped critique of the slimness or beauty myths and show themselves to be perfectly aware of the causes and consequences of such ideals. This is particularly so of the most self-reliant women, who have their own life project and/or have been most influenced by feminism (beyond their families or other relationships). Feminism, together with an atypical experience of the body, outside of the usual social expectations for women (in sport, for example) are fundamental factors in the generation of an alternative vision. Moreover, in these contexts, there is not such a clear differentiation between the masculine and feminine cultivation of body image.

Another observation we have made is that despite the social pressure to comply to a certain image that these girls share with other young women, they have their own alternative aesthetic criteria: comfort, functionality and a sense of corporal integrity. As well as being critical of aesthetical cultural mandates they are also freer to try out new individual or alternative ways of presenting themselves. Furthermore, a specific body or dress choice (not removing body hair or dressing in a counter-cultural fashion, for example) becomes a way of expressing a reaction against their parents, friends or society in general. The body is a privileged space of social and gender control, 
which results in rebellion and resistance being addressed to the body as well. In this sense, what is considered to be an appearance that simply follows fashion (wearing a miniskirt or high-heels, for instance) could become a symbol of transgression and rupture when displayed in certain contexts considered to be masculinized or desexualized, as is the case with bertsolaritza $a^{15}$.

Similarly, we have perceived new models of masculinities in young men. These boys risk being labelled "freaky" for situating themselves outside the circles of hegemonic masculinity, such as football, and inside those which are socially considered feminine, connected to emotions or care.

Awareness of inequalities between women and men goes hand in hand with the development of a general social conscience. Besides the ideological factor, another element that has emerged as relevant in our research is the separation from one's family or group in which one has been socialized, particularly when those environments foster inequality. This separation involves the search for or use of new spaces (studies and readings, sport or artistic activity) and also the physical separation from or confrontation with parents and/or friends, yielding new forms of socialization, new relationships and friendships or a reconfiguration of one's group of friends. It becomes evident that in many cases breaking with old spaces and relationships is crucial to forming new friendships, sexual or intimate relationships and inventing new body practices or new forms of performativity.

\section{In conclusion}

Youth is characterized by its diversity, complexity and non-linearity of its expressions, a complexity related directly to factors such as gender, class or the social and economic environment in which it lives. This complexity has been linked by authors like Manuela Du Bois Reymond (1995) to the emergence of 'choice biography', a vision which, however, for Andy Furlong, Fred Cartmel and Andy Biggart (2006) can entail the masking of situations of vulnerability, risk and inequality experienced by young people, especially those with less education and social possibilities, in whose biographies non-linearity does not correspond at all to the possibility of choice.

At this level, the fact that the young people interviewed in our research live in a society committed both socially and institutionally to equality, as well as the fact that most of them are currently completing or already possess a university education, certainly influences the results obtained. This could have favoured, for example, the pres-

\footnotetext{
${ }^{15}$ Bertsolaritza is one of the most important and popular cultural manifestations in Basque society. Verses are improvised in public (as a performance) and words are accompanied by melody, rhyme and metrics.
} 
ence of quite a few people with a significant level of choice biographies, as well as alternative approaches with regard to their own life project, gender identity, body image or forms of cohabitation. In any event, we believe that, besides educational level or social class of origin, understanding the whole complexity of these diverse and/or disruptive options in relation to gender implies identifying and bearing in mind certain factors about which it is necessary to keep on researching into and which could be taken into account in social policies aimed at equal opportunities.

Why is it that some young people break away and others don't? Besides the recent socio-historical context being more conducive to change, the data obtained in this research suggests that, there are other elements related to more specific and personal contexts, such as: attitudes and behaviour of family in general and mothers in particular, or the existence of female references (teachers, friends, fictional characters...) who opened the way for those coming after them or, as we have said above, re-socialization in an alternative or change-enabling milieu are also important. In the case of young women, the group of girlfriends stands out as a fundamental reference against the background of feminism, directly or indirectly.

Specifically, the interest of anthropological studies of youth lies in the research topic's potential to crystallize some of the elements condensed in the continuity-conflict-change dynamic of society as a whole. Moreover, when we analyse young women and men from a feminist viewpoint, our attention is drawn to hegemonic and alternative discourses, to early forms of socialization (family, school), to institutional spaces, to specific practices and to the debates about achieved (and not achieved) equality. This multiple all-embracing look at the representations and practices of young Basque people has allowed us to identify transformations in individual and group conduct, as well as the different factors behind such transformations, but also to recognize continuities and conflicts, and what we have termed the black spots in gender relations.

At this level, we think that the persistence of a dichotomous and naturalized vision of all things masculine/feminine, which is projected in very different aspects and walks of life (identity, appearance, work, motherhood, sexuality...), and which is fuelled specifically by the consumer industry (music, music videos, cinema, series, advertising...), implies a fundamental obstacle to gender equality. Nowadays, the norms of sexual difference are not transmitted, or not just transmitted, by the law, the state or formal education, but they are spread via the mass media and the culture of leisure. This forces us to modify our thinking as regards not just the analyses but also the social measures to be implemented. 
Even so, nor should we lose sight of the fact that the Spanish State, like other European countries, has an educational system in which there has been comparatively more progress in neutralizing class segregation at the different levels of the system than in that regarding gender differences (Iannelli \& Smyth, 2008). All of this prevents young people from reflecting calmly on the problems and limits of a differentialist perspective and what the differences imply in terms of unequal relations of power and job access.

Continuing with the black spots, we want to emphasize the harmful influence of the boom in a completely romanticised love ideology, which is applied both to couples' relationships and to maternity, and which specifically affects girls, shaping their visions and practices with respect to life projects or choices regarding studies and employment. Second, the negativity of a heteronormative hegemonic sexual ideology which forces women to develop but at the same time limit their expressions of desire, in a difficult and perverse exercise, is also worth underlining.

Moreover, the existing association in Basque and Spanish society, also demonstrated in our study, between gender inequality and violence against women, brings with it both positive and negative consequences at the same time. On the one hand, society in general is increasingly aware of the scourge implied by sexist violence and many young people are reacting against this; yet, at the same time, this emphasis leads to other questions involving the subordination of women being relegated to a secondary level or disappearing altogether. And when this is linked, furthermore, to the rejection of feminism, which affects broad sections of society, it leaves young people without any resources when it comes to analysing their own experiences and confronting their contradictions.

Finally, this research also invites us to look towards the future through young people's hopes, desires and dreams, their professional or social ambitions, imagined models of cohabitation or family. Young people are caught in transition, negotiating a path between the equality already achieved, the equality they hope for in their plans for the future and the tensions and contradictions of the present. A puzzle where some of the pieces fit, but many others do not.

\section{References}

Alberdi, Inés; Escario, Pilar \& Matas, Natalia (2000). Las mujeres jóvenes en España. Barcelona: Fundación "La Caixa".

Álvarez Molés, Pili (2012). Movimientos sociales, relaciones de género y cultura. El caso de los gaztetxes en Euskadi. Retrieved from: 
Mari Luz Esteban Galarza; Jone Miren Hernández García; Elixabete Imaz Martínez

http://www.gipuzkoagazteria.net/gestor/nodos/nodo dok din/Relaciones de genero y cultura en gaztetxes de la CAPV.pdf

Amurrio, Mila (Coord.) (2008). Violencia de género en las relaciones de pareja de adolescentes y jóvenes de Bilbao (Conclusiones del informe). Retrieved from: http://www.bilbao.net/cs/Satellite? $\mathrm{c}=\mathrm{BIO}$ Generico FA\&cid $=3000910950 \&$ language $=$ en $\&$ pageid $=3000059210 \& \mathrm{pa}$ gename=Bilbaonet\%2FBIO Generico FA\%2FBIO generico

Ararteko/ Gobierno Vasco (Eds.) (2009). Adolescentes y jóvenes lesbianas, gays, transexuales y bisexuales. Dificultades y rechazos en su desarrollo personal, en sus relaciones y en su socialización. Vitoria-Gasteiz:

Argoitia, Naroa (2011). Gazteak eta berdintasuna. Nola bizi dute? Vitoria-Gasteiz: Eusko Jaurlaritzaren Argitalpen Zerbitzu Nagusia.

Arregui, Begoña (1987). Evolución demográfica y cambio socioeconómico: Modernización y mujer en el País Vasco. In Teresa del Valle, Carmen Larrañaga, Carmen Pérez, Begoña Arregui \& Lourdes Méndez (Eds.), La mujer y la palabra (pp. 51-93). San Sebastián: La Primitiva Casa Baroja.

Bantigny, Ludivine \& Jablonka, Ivan (Eds.) (2009). feunesse oblige. Histoire des jeunes en France XIXè-XXIè s. Paris: PUF.

Basque Government (2016). The unemployment level amongst the population in the Basque Autonomous Community aged 16 to 29 was 25.6\%. Retrieved from http://www.euskadi.eus/gobierno-vasco/-/noticia/2016/tasa-de-paro-de-lajuventud-en-el-cuarto-trimestre-de-2015-es-del-25/

Basque Youth Observatory (2016). The number of young people fell by half. Retrieved from http://www.gazteaukera.euskadi.eus/noticia/2016/la-poblacion-jovensigue-descendiendo-en-euskadi/r58-7657/es/

Bidart, Claire \& Pellissier, Anne (2002). Copains d'école, copains de travail. Evolution des modes de sociabilité d'une cohorte de jeunes. Réseaux, 20(115), 17-49. https://doi.org/10.3917/res.115.0017

Bourdieu, Pierre (1979/1984). Distinction: A Social Critique of the Fudgement of Taste. London: Routledge.

Bullen, Margaret \& Díez, Carmen (2002). Violencia y cambio de culturas androcéntricas. En IX Congreso de Antropología de la FAAEE, Barcelona, septiembre 2002.

Bullen, Margaret \& Egido, José Antonio (2003). Tristes espectáculos: las mujeres y los Alardes de Hondarribia y Irun. Bilbao: Servicio Editorial de la UPV-EHU.

Bullen, Margaret \& FARAPI (2011). El entorno en que se produce la violencia de género y sus causas en Gipuzkoa. Donostia: Diputación Foral de Gipuzkoa.

Bustelo, María \& Lombardo, Emanuel (2007). Políticas de Igualdad en España y en Europa. Madrid: Cátedra.

Butler, Judith (1993). Bodies that Matter. New York: Routledge.

Butler, Judith (1997). Performative Acts and Gender Constitution: An Essay in Phenomenology and Feminist Theory. In Katie Conboy, Nadia Medina \& 
Sarah Stanbury (Eds.), Writing on the body. Female Embodiment and Feminist Theory (pp. 401-417). New York: Columbia University Press.

Casado, Irina (2006). En los escenarios del tiempo. Organización sociocultural de la procreación e identidad en Oslo. Perifèria, 4, 1-34.

Comas d`Argemir, Dolors (2011). La violencia sobre las mujeres en la agenda política, en la sociedad y en los medios de comunicación, Ankulegi 15, 175-190.

Connell, Raewyn (1987). Gender and Power. Society, the Person and Sexual Politics. Stanford: Stanford University Press.

De Miguel Álvarez, Ana (2008). Feminismo y juventud en las sociedades formalmente igualitarias. Revista de juventud, 83, 29-45.

Del Valle, Teresa (1997). Andamios para una nueva ciudad: lecturas desde la antropología. Madrid: Cátedra.

Del Valle, Teresa (Coord.) (2002). Modelos emergentes en los sistemas y las relaciones de género. Madrid: Narcea.

Díez, Carmen (1996). Deporte y construcción de las relaciones de género. Gazeta de Antropología, 12, 1-14.

Díez, Carmen (1999). Maternidad y orden social. Vivencias del cambio. In Teresa del Valle (Ed.), Perspectivas feministas desde la antropología social (pp. 155-185). Barcelona: Ariel Antropología.

Díez, Carmen (2003). Deporte, socialización y género. In F. Xavier Medina \& Ricardo Sánchez (Eds.), Culturas en juego (pp. 159-179). Barcelona: Icaria.

Díez Mintegui, Carmen; Hernández García, Jone M. (2008). ¿Acaso no hay diosas en el Olimpo? Práctica deportiva y sistema de género: apuntes de una investigación en marcha. In Luis Cantarero, F. Xavier. Medina \& Ricardo Sánchez, (Coords.), Actualidad en el deporte: investigación y aplicación (pp. 147-163). Donostia: Ankulegi.

Du Bois-Reymond, Manuela. (1995). Future Orientations of Dutch Youth: The Emergence of a Choice Biography. In Alessandro Cavalli \& Olivier Galland (Eds.), Youth in Europe (pp. 201-220). London: Pinter.

Elzo, Javier (2005). Chicos y chicas: tan similares y tan distintos. Educación social: Revista de intervención socioeducativa, 29, 39-62.

EMAKUNDE (2015). Cifras 2015. Mujeres y hombres en Euskadi. Retrieved from: http://www.emakunde.euskadi.eus/contenidos/informacion/servicio cifras/es emakunde/adjuntos/cifras 2015.pdf

Esteban, Mari Luz (2004). Antropología del cuerpo. Género, itinerarios corporales, identidad y cambio. Barcelona: Edicions Bellaterra.

Esteban, Mari Luz (2011). Crítica del Pensamiento Amoroso. Barcelona: Edicions Bellaterra.

Esteban, Mari Luz \& Amurrio, Mila (Eds.), Feminist Challenges in the Social Sciences: Gender Studies in the Basque Country. UPV/EHU Current Research Series. Center for Basque Studies, University of Nevada, Reno.

Esteban, Mari Luz \& Távora, Ana (2008). El amor romántico y las subordinación social de las mujeres: revisiones y propuestas. Anuario de Psicología,39(1), 59-73. 
Retrieved from:

http://cdd.emakumeak.org/ficheros/0000/0598/2225 3.ElAmorRomantico.pdf

Estébanez, Ianire \& Vázquez, Norma (2013). La desigualdad de género y el sexismo en las redes sociales. Vitoria-Gasteiz: Eusko Jaurlaritzaren Argitalpen Zerbitzu Nagusia.

Euskal Irrati Telebista. Basque public broadcast service (2016). Sociedad. Retrieved from http://www.eitb.eus/es/noticias/sociedad/detalle/4062906/el-numerojovenes-euskadi-se-reduce-mitad-2011-2014/

Eurostat Statistical Books (2015). Being young in Europe today. Luxembourg: Publications Office of the European Union. Retrieved from: http://ec.europa.eu/eurostat/documents/3217494/6776245/KS-05-14-031-ENN.pdf/18bee6f0-c181-457d-ba82-d77b314456b9

Feixa, Carles (1996). Antropología de las edades. In Joan Prat \& Angel Martínez (Eds.), Ensayos de antropología cultural (pp. 319-334). Barcelona: Ariel Antropología.

Feixa, Carles (1998). De jóvenes, bandas y tribus. Barcelona: Ariel Antropología.

Feixa, Carles (2005). La habitación de los adolescentes. Papeles del CEIC, 16, 1-21.

Feixa, Carles \& Porzio, Laura (2004). Los estudios sobre culturas juveniles en España (1960-2003). Estudios de Fuventud, 64, 9-28.

Fernández-Llebrez González, Fernando \& Camas García, Francisco (2010). Cambios y persistencias en la igualdad de género de los y las jóvenes en España (1990-2010). Madrid: INJUVE-Estudios.

Furlong, Andy; Cartmel, Fred \& Biggart, Andy (2006). Choice biographies and transitional linearity: Re-conceptualising modern youth transitions. Papers, 79, 225-239. https://doi.org/10.5565/rev/papers/v79n0.834

García Campos, Juan Manuel (2015, June 13). Ranking de desempleo juvenil en Europa: España, líder con el 49,6\%. La Vanguardia. Retrieved from http://www.lavanguardia.com/vangdata/20150613/54432243021/ranking-dedesempleo-juvenil-en-europa-espana-lider-con-el-49-6.html

García García, Antonio (2010). Exponiendo hombría. Los circuitos de hipermasculinidad en la configuración de las prácticas sexistas entre los varones jóvenes. Revista de Estudios de fuventud, 89, 59-78.

Garrido, Luís M. (1992). La doble biografía de la mujer española. Madrid: Instituto de la Mujer- MTAS.

Gaviria, Sandra (2005). De la juventud hacia la edad adulta en Francia y en España. Revista de estudios de juventud, 71, 29-39.

Gehitu (Berdindu Gipuzkoa) \& Guztiok Elkartea (Berdindu Eskolak) (2014). Actitudes respecto a la diversidad afectivo-sexual en las aulas, curso 2013-14. VitoriaGasteiz: Gobierno Vasco. Retrieved from: http://www.gizartelan.ejgv.euskadi.eus/contenidos/informacion/berdindu/es berdindu/adjuntos/actitudes\%20an\%20la\%20diversidad\%20afectivo-sexual.pdf

Giddens, Anthony (1984). The Constitution of Society. Outline of the Theory of Structuration. Cambridge: Polity. 
Griffin, Christine; Szmigin, Isabelle; Bengry-Howell, Andrew; Hackley, Chris \& Mistral, Willm (2013). Inhabiting the contradictions: Hypersexual femininity and the culture of intoxication among young women in the UK. Feminism \& Psychology, 23(2), 184-206. https://doi.org/10.1177/0959353512468860

Guillo Arakistain, Miren (Coord.) (2016). Festak, genero-harremanak eta feminismoa. Donostia: UEU Udako Euskal Unibertsitatea.

Hays, Sharon (1998). Las contradicciones culturales de la maternidad. Barcelona: Paidós. Hernández, Jone M. \& Imaz, Elixabete (2010). Demythicizing, Unveiling, Challenging: A Review of Twenty-five Years of Feminist Academic Production (1985-2010). In Mari Luz Esteban \& Mila Amurrio (Eds.), Feminist Challenges in the Social Sciences: Gender Studies in the Basque Country (pp. 55-70). Reno: Center for Basque Studies, University of Nevada.

Iannelli, Cristina \& Smyth, Emer (2008). Mapping gender and social background differences in education and youth transitions across Europe. Fournal of Youth Studies, 11(2), 213-232. https://doi.org/10.1080/13676260701863421

Imaz, Elixabete (2010). Convertirse en madre: etnografía del tiempo de gestación. Cátedra: Madrid.

Imaz, Elixabete (2016). Las madres bricoleurs. Estrategias, prácticas y modelos maternales contemporáneos, Estudos Feministas, 24 (2), 485-497. http://dx.doi.org/10.1590/1805-9584-2016v24n2p485.

Juliano, Dolores (1992). El juego de las astucias: mujer y construcción de modelos sociales alternativos. Madrid: Horas y Horas.

Juliano, Dolores (1998). Las que saben. Subculturas de mujeres. Madrid: Horas y Horas.

Lasén, Amparo (1999). Le devenir fémenin des temporalités juveniles. Cahiers $d u$ Genre, 24, 99-114.

Liimakka, Satu (2008). The influence of cultural images and other people on young women's embodied agency. Young, 16, 131-152. https://doi.org/10.1177/110330880801600202

Liotard, Philippe \& Jamain-Samson, Sandrine (2011). La "Lolita" et la "sex bomb", figures de socialisation des jeunes filles. Lhypersexualisation en question. Sociologie et sociétés, 43(1), 45-71. https://doi.org/10.7202/1003531ar

López Oller, Joffre (2014) El coste de la emancipación residencial en Euskadi 2014.

Retrieved from: http://www.gazteaukera.euskadi.eus/contenidos/informacion/emantzipazioa/es def/adjuntos/emantzipazio kostua 15 c.p $\underline{\mathrm{df}}$

Martínez, Roger (2002). Culture juvenil i genere. Barcelona: Observatori Catalá de la Juventut.

Martínez González, María (2007). Jóvenes y Feminismo: ¿hacia un feminismo de la "subversión"? Inguruak: Revista Vasca de Sociología y Ciencia Política, 43, 97116.

Masa, Marce (2009). Adolescentes en Euskadi. Una aproximación desde el empoderamiento. Vitoria-Gasteiz: Emakunde. 
McRobbie, Angela (2009). The Aftermath of Feminism: gender, culture and social change. London. Sage.

Medina Doménech, Rosa M. (2012). Sentir la historia. Propuestas para una agenda de investigación feminista en la historia de las emociones. Arenal, 19(1), 161-199.

Miranda, María Jesús (1987). Crónicas del desconcierto. Madrid: Ministerio de Cultura/Instituto de la Mujer.

Moreno, Almudena (2012). The transition to adulthood in Spain in a comparative perspective: the incidence of structural factors. Young, Nordic fournal of Youth Resear, 20, 19-48. https://doi.org/10.1177/110330881102000102

Ortner, Sherry B. (1984). Theory in Anthropology since the Sixties. Society for Comparative Study of Society and History, 26(1), 126-166. https://doi.org/10.1017/s0010417500010811

Pichardo, Ignacio (Ed.) (2009). Adolescentes ante la diversidad sexual. Madrid: Catarata.

Ramos, Ramón (1990). Cronos dividido. Uso del tiempo y desigualdad entre mujeres y hombres en España. Madrid: MTAS-Instituto de la Mujer.

Roca i Girona, Jordi (1996). De la pureza a la maternidad. La construcción del género femenino en la posguerra española. Madrid: Ministerio de Educación y Ciencia.

Romo Avilés, Nuria (2001) Mujeres y drogas de síntesis. Género y riesgo en la cultura del baile. Donostia: Gakoa-Tercera Prensa.

Saltzman, Janet (1991). Gender Equity. Newbury Park: Sage.

Scharff, Christina (2012). Repudiating Feminism. Young Women in a Neoliberal World. Surrey, England: Ashagte Publishind Limited.

Tobío, Constanza (2005). Madres que trabajan (Dilemas y estrategias). Madrid: CátedraFeminimos.

University of the Basque Country. (2011). Women and men at the University of the Basque Country. Retrieved from:

http://www.ehu.eus/documents/2007376/0/Mujeres y hombres en upv II di agnostico 2011

Walter, Natasha (2012). Muñecas vivientes. El regreso del sexismo. Madrid: Turner.

Zulaika, Joseba (1989). Chivos y soldados. Donostia: La Primitiva Casa Baroja.

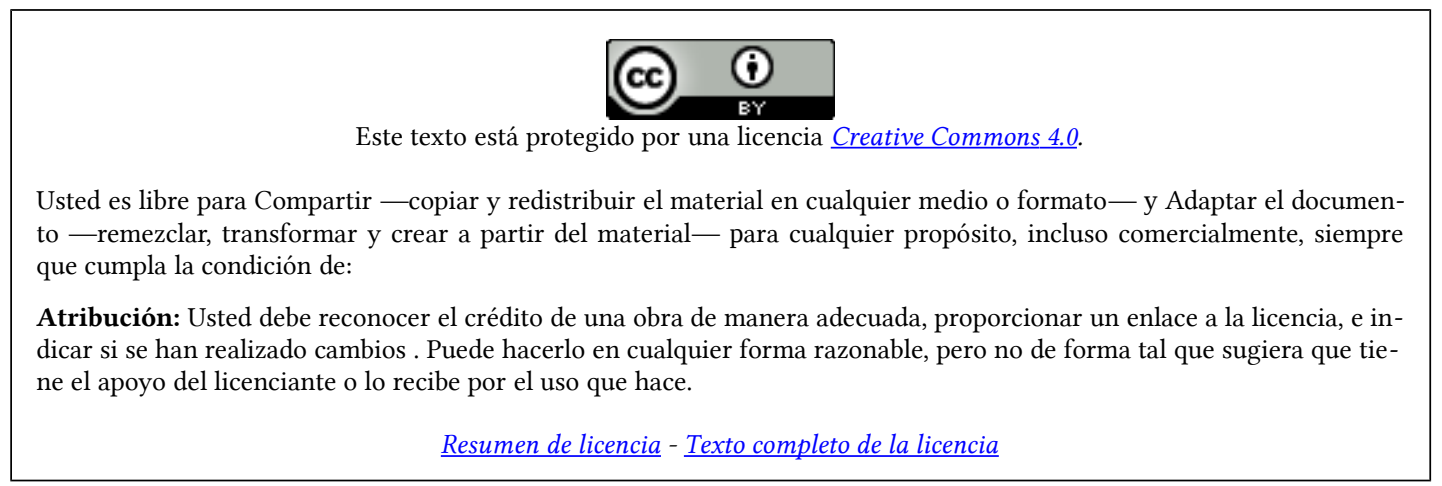

